\title{
TACR1 Gene
}

National Cancer Institute

\section{Source}

National Cancer Institute. TACR1 Gene. NCI Thesaurus. Code C41021.

This gene plays a regulatory role in phosphatidylinositol metabolism of substance P. 